Hugo, W. B. (1956). J. gen. Microbiol. 15, 315-323

\title{
The Action of Phenol and 2-Phenoxyethanol on the Oxidation of Various Substances by Escherichia coli and by a Disrupted Cell Preparation of the Organism
}

\author{
By W. B. HUGO \\ Department of Pharmacy, The University, Nottingham
}

\begin{abstract}
SUMMARY: The effects of phenol and 2-phenoxyethanol on the oxygen uptake of washed suspensions and a disrupted cell preparation of Escherichia coli, with different substrates, has been further investigated. Stimulation of oxygen uptake with mannitol or glucose as substrate was not due to an increase in the viable population or associated with an uncoupling effect. The results obtained with a disrupted cell preparation capable of oxidizing glucose and lactic acid to pyruvic acid, on comparison with results with intact organisms, suggest that enzyme location may account for the differences in inhibitory activity obtained with different substrates.
\end{abstract}

Hugo \& Street (1952) showed that the action of phenol and 2-phenoxyethanol (phenoxetol) on the course of oxygen uptake by washed suspensions of Escherichia coli differed markedly with different substrates. In the presence of phenol $(0 \cdot 1-0.2 \%, \mathrm{w} / \mathrm{v} ; 0.010-0.021 \mathrm{M})$ and 2-phenoxyethanol $(0 \cdot 1-0.2 \%$, $\mathrm{w} / \mathrm{v} ; 0.007-0.014 \mathrm{M})$ a stimulation of the rate of oxygen uptake of the order of 10-20\% occurred when glucose, mannitol or lactose was used as substrate; these same doses inhibited the rate of oxygen uptake by $10-15 \%$ when succinate, lactate, pyruvate or acetate was the substrate. These results were difficult to explain on the hypothesis that these two antiseptics are non-specific protoplasmic poisons. Three working hypotheses were considered in an attempt to explain these effects of substrate on the response of oxygen uptake to the antiseptics: (i) that the differences reflect changes in the population of viable organisms: (ii) that the stimulations of oxygen uptake were associated with an uncoupling effect such as is shown by the nitrophenols; (iii) that the differences could be attributed to an effect of the antiseptic on permeability of the organisms to substrate, coupled with differences in the location of the enzymes involved in the oxidation of different substrates. The experiments now described were undertaken to evaluate these hypotheses.

\section{METHODS}

Chemicals. Diphosphopyridine nucleotide (DPN) and adenosine triphosphate (ATP) were samples supplied by Messrs L. Light and Co. Ltd.; the former when assayed by the method of Racker (1950) was found to contain $82 \%$, w/w, DPN. Sugars and mannitol were of bacteriological grade as supplied by Messrs $\mathbf{T}$. Kerfoot Ltd. The 2-phenoxyethanol was a sample which complied with the requirements of the British Pharmaceutical Codex. The methylene blue was a 
sample from Messrs Hopkins and Williams Ltd.; all other chemicals were of A.R. quality. The 2:4-dinitrophenol (DNP) was recrystallized twice from ethanol. Lactic acid was neutralized to $\mathrm{pH} \mathbf{7 \cdot 0}$ with sodium hydroxide; sodium pyruvate was prepared by the method of Robertson (1942). Phosphate buffers were prepared from $\mathrm{KH}_{2} \mathrm{PO}_{4}$ and $\mathrm{Na}_{2} \mathrm{HPO}_{4} \cdot 12 \mathrm{H}_{2} \mathrm{O}$ and the $\mathrm{pH}$ value checked electrometrically. Ringer's solution (quarter strength) was prepared from solution tablets (Messrs Oxo Ltd.).

Growth of organisms. Escherichia coli (NCTC 5934) was grown for $48 \mathrm{hr}$. on a tryptic digest agar $(125 \mathrm{ml}$.) contained in a 1 l. Roux flask, harvested in quarter-strength Ringer's solution, washed twice with this solution and standardized nephelometrically to contain $6 \cdot 4 \mathrm{mg}$. dry wt. organism $/ \mathrm{ml}$.

Oxygen uptakes were determined by the direct method of Warburg. The gas phase was air and measurements were made at $37^{\circ}$ with a shaking rate of 100 oscillations/min. Unless otherwise stated, the main compartment of the Warburg vessel contained $1 \mathrm{ml}$. of substrate $(0.02 \mathrm{M})$ in phosphate buffer $(0.05 \mathrm{M}, \mathrm{pH} 7 \cdot 0)$, and $0.5 \mathrm{ml}$. of antiseptic solution or DNP; the side arm contained $0.5 \mathrm{ml}$. of standardized bacterial suspension; the centre well $0.2 \mathrm{ml}$., $20 \% \mathrm{KOH}$, and folded filter-paper. 2-Phenoxyethanol is soluble in 43 parts of water at $15 \cdot 5^{\circ}$. This fact necessitated a change in the above scheme when studying higher concentrations, which is described in the appropriate section.

Viable counts were made by serial dilution in quarter-strength Ringer's solution and plating on tryptic digest agar.

Disruption of the bacterial cells. Bacteria (2.5 g. wet weight), harvested from slopes in Roux bottles, were placed in the containers of the Mickle apparatus together with $3 \mathrm{ml}$. water and $5 \mathrm{~g}$. of $1 \mathrm{~mm}$. diameter 'Ballotini' beads, and were well chilled in melting ice. The tubes were then vibrated for $\mathbf{4 0}$ min., rechilled and vibrated for a further $\mathbf{4 0} \mathrm{min}$. Almost complete disruption of the bacteria was achieved, as judged by the inspection of stained preparations. The contents of the tubes were transferred to a centrifuge tube by using $2 \times 1.5 \mathrm{ml}$. of water and spun at 3000 r.p.m. for $30 \mathrm{~min}$. The turbid supernatant fluid, c. $5 \mathrm{ml}$., was removed from the deposit of 'Ballotini' beads and larger cell fragments by means of a pipette and re-centrifuged at 19,000 r.p.m. in a refrigerated centrifuge (Measuring and Scientific Equipment Ltd.). This resulted in a yellow supernatant fluid and a light flocculent deposit. This yellow supernatant fluid contained no living organisms, but on examination in a bright light was seen to be slightly opalescent.

\section{RESULTS}

\section{Oxygen uptake and viability}

Viable counts were performed on the contents of the Warburg flasks after completion of the oxygen uptake experiments. The changes in counts and oxygen uptakes expressed as a percentage of the control are compared in Table 1, in which it can be seen that although there was a slight decrease in count there was no relationship between decrease in count and oxygen uptake. By serially diluting bacterial suspensions it was shown that, in the absence of antiseptics, oxygen uptake was directly proportional to the viable cell content of the 
suspensions over the range corresponding to $3 \cdot 2-0 \cdot 32 \mathrm{mg}$. dry wt. bacteria/flask, so that oxygen uptake paralleled viable count and a decrease in number of viable organisms would result in a proportionate decrease in the oxygen uptake rate. The lack of correspondence between viable counts and oxygen uptake in the presence of antiseptic at low concentrations showed that the oxygen uptake responses were being determined by some other factor(s).

Table 1 . The effect of $0 \cdot 1 \%$ phenol and $0.2 \%$ 2-phenoxyethanol on the viable count and rate of oxygen uptake $\mu l . /$ min. of Escherichia coli at $37^{\circ}$

\begin{tabular}{|c|c|c|c|c|}
\hline \multirow[b]{2}{*}{ Substrate } & \multicolumn{2}{|c|}{$0.1 \%$ phenol } & \multicolumn{2}{|c|}{$0.2 \%$ 2-phenoxyethanol } \\
\hline & $\begin{array}{c}\text { Viability, \% of } \\
\text { control without } \\
\text { phenol }\end{array}$ & $\begin{array}{l}\text { Rate of } \mathrm{O}_{2} \text { up- } \\
\text { take, \% of control } \\
\text { without phenol }\end{array}$ & $\begin{array}{l}\text { Viability, \% of } \\
\text { control without } \\
\text { 2-phenoxyethanol }\end{array}$ & $\begin{array}{l}\text { Rate of } \mathrm{O}_{2} \text { uptake, } \\
\% \text { of control without } \\
\text { 2-phenoxyethanol }\end{array}$ \\
\hline Mannitol & 93 & $121 \cdot 6$ & $96 \cdot 7$ & $128 \cdot 2$ \\
\hline Glucose & $94 \cdot 2$ & $\mathbf{1 1 0} \cdot 3$ & 94 & 108 \\
\hline Glycerol & $99 \cdot 4$ & $96 \cdot 5$ & $100 \cdot 2$ & $\mathbf{9 3 \cdot 5}$ \\
\hline Lactate & 96 & $73 \cdot 3$ & $95 \cdot 7$ & 65 \\
\hline Succinate & $95 \cdot 8$ & $45 \cdot 3$ & $95 \cdot 3$ & $61 \cdot 4$ \\
\hline
\end{tabular}

At phenol concentrations of $0 \cdot 75-1.0 \%, \mathrm{w} / \mathrm{v}(0 \cdot 079-0 \cdot 106 \mathrm{M})$ and 2-phenoxyethanol concentrations of $1 \cdot 0-1 \cdot 2 \%, \mathrm{w} / \mathrm{v}(0 \cdot 072-0.086 \mathrm{M})$ a slow but measurable oxygen uptake on lactate in the first case and on lactate or succinate in the second case occurred, despite the fact that these high antiseptic concentrations sterilized the contents of the Warburg flask in $30 \mathrm{~min}$. These same concentrations caused an abrupt and complete cessation of oxygen uptake with the following substrates: mannitol, glucose, lactose, pyruvate, glycerol.

\section{Comparison of the behaviour of phenol, 2-phenoxyethanol and $2: 4$-dinitrophenol}

Nitrophenols are known to stimulate the rate of respiration of bacteria (Shoupe \& Kimler, 1934) and to cause the complete oxidation of substrates in certain cases by inhibiting assimilation (Clifton, 1937). In the experiments reported above and in earlier work (Hugo \& Street, 1952) the concentration of substrate was maintained in excess so that depletion of substrate would not occur. In the present experiments it was necessary to investigate complete oxidation and hence the concentrations of substrate were adjusted to ensure that the total volume of oxygen required could be measured on the manometer scale. Mannitol and glucose at $2.5 \times 10^{-3} \mathrm{M}$ and lactate at $5 \times 10^{-3} \mathrm{M}$ were used as substrates. Otherwise the conditions were as stated under methods and as used in previous experiments (Hugo \& Street, 1952). The concentrations of inhibitors were: phenol $0.1 \% \mathrm{w} / \mathrm{v}(0.010 \mathrm{M}), 2$-phenoxyethanol $0.2 \% \mathrm{w} / \mathrm{v}$ (0.014 M), 2:4-dinitrophenol $2.5 \times 10^{-4} \mathrm{M}$.

The results are shown in Table 2, where it can be seen that neither phenol nor 2-phenoxyethanol (at concentrations stimulatory to the rate of oxygen uptake) significantly increased the total oxygen uptake. In contrast, 2:4dinitrophenol caused an increase in the total oxygen consumption. This, 
however, did not reach the theoretical value for complete oxidation; other reports record the complete oxidation of substrates by Escherichia coli in the presence of this concentration of the nitrophenol (Clifton, 1937).

Table 2. Comparison of the effect of phenol, 2-phenoxyethanol and 2:4-dinitrophenol on the oxidation of mannitol, glucose and lactate by washed suspensions of Escherichia coli

\begin{tabular}{|c|c|c|c|c|c|c|}
\hline Substrate & Expt. & Control & $\begin{array}{c}\text { With } \\
\text { 0.010 M- } \\
\text { phenol }\end{array}$ & $\begin{array}{c}\text { With } \\
\text { 0.014 M- } \\
\text { phenoxetol }\end{array}$ & $\begin{array}{c}\text { With } \\
2.5 \times 10^{-1} 2: 4- \\
\text { dinitrophenol }\end{array}$ & $\begin{array}{l}\text { Theoretical } \\
\text { oxygen uptake } \\
\text { for complete } \\
\text { oxidation, } \mu \mathrm{l} \text {. }\end{array}$ \\
\hline \multicolumn{7}{|c|}{ Total oxygen uptake, $\mu \mathrm{l}$. } \\
\hline $\begin{array}{l}\text { Mannitol, } \\
2.5 \times 10^{-3} \mathrm{M}, \\
1.0 \mathrm{ml} .\end{array}$ & $\begin{array}{l}1 \\
2\end{array}$ & $\begin{array}{l}217 \\
222\end{array}$ & $\begin{array}{l}215 \\
213\end{array}$ & $\begin{array}{l}219 \\
217\end{array}$ & $\left.\begin{array}{l}294 \\
286\end{array}\right\}$ & 364 \\
\hline $\begin{array}{l}\text { Glucose, } \\
2.5 \times 10^{-3} \mathrm{M}, \\
1.0 \mathrm{ml}\end{array}$ & $\begin{array}{l}1 \\
\mathbf{2}\end{array}$ & $\begin{array}{l}230 \\
237\end{array}$ & $\begin{array}{l}224 \\
243\end{array}$ & $\begin{array}{l}219 \\
231\end{array}$ & $\left.\begin{array}{l}277 \\
283\end{array}\right\}$ & 336 \\
\hline $\begin{array}{l}\text { Lactate, } \\
5.0 \times 10^{-8} \mathrm{M}, \\
1.0 \mathrm{ml} .\end{array}$ & $\begin{array}{l}1 \\
\mathbf{2}\end{array}$ & $\begin{array}{l}214 \\
224\end{array}$ & $\begin{array}{l}227 \\
218\end{array}$ & $\begin{array}{l}209 \\
228\end{array}$ & $\left.\begin{array}{l}291 \\
287\end{array}\right\}$ & 336 \\
\hline
\end{tabular}

Fig. 1 also illustrates the difference in behaviour of phenol and $2: 4$-dinitrophenol. With mannitol or glucose as substrates all three compounds stimulated the rate of oxygen uptake but only the dinitrophenol affected the total oxygen consumption. With lactate as substrate the rate of oxygen uptake was not stimulated by any of the three compounds, though with dinitrophenol the total oxygen uptake was increased.

\section{Permeability and enzyme location}

Information concerning the role of permeability was sought by comparing the activities of intact and disrupted organisms and the action of antiseptics upon these two systems. Oxygen uptakes of the order of $60 \mu \mathrm{l} . / \mathrm{hr}$. occurred when the disrupted organism preparation was incubated with lactate as substrate, and the production of pyruvic acid was demonstrated in the pooled contents of five Warburg flasks by paper chromatography of the 2:4-dinitrophenylhydrazone according to the method of Cavallini, Frontalli \& Toschi (1949). Pyruvate itself was not oxidized by the preparation.

The dry weight of the disrupted organism preparations lay between 14 and $18 \mathrm{mg} . / \mathrm{ml}$. The $Q_{0_{2}}$ value for lactate ranged between 3.3 and $4 \cdot 3$. The average $Q_{0_{2}}$ value with the intact organism was 88 and thus the activity of the disrupted organism was of the order of $1 / 20$ to $1 / 27$ that of intact organisms.

The preparation was without action on glucose. However, addition of DPN, ATP, MB and $\mathrm{Mg}^{++}$showed that addition of DPN caused a significant oxygen uptake in the presence of glucose (Table 3 ) and led to the production of pyruvic acid. It will also be observed that the oxygen uptake was greater in the absence of glucose (flask 12) than in the absence of DPN (flask B) and it is possible that 


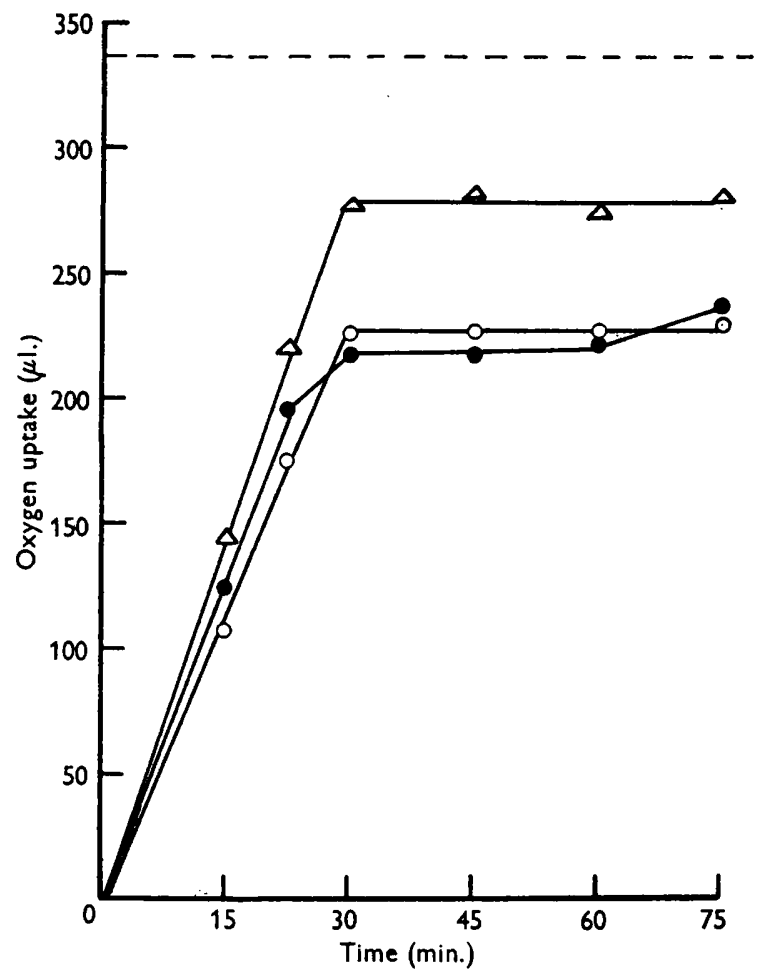

Fig. 1. Comparison of the action of phenol $(0.010 \mathrm{M}),-2$, and 2 :4-dinitrophenol $\left(2.5 \times 10^{-4} \mathrm{M}\right), \triangle \longrightarrow \triangle$, on the oxidation of $1.0 \mathrm{ml}$. of $2.5 \times 10^{-8} \mathrm{M}$-glucose by $0.5 \mathrm{ml}$. of a washed suspension of Escherichia coli containing 6.4 mg. dry wt. bacteria $/ \mathrm{ml}$. O-O, uptake in the absence of an inhibitor; - - - , uptake level for complete oxidation.

Table 3. The effect of cofactors and methylene blue on the oxidation of glucose by a disrupted bacterial preparation from Escherichia coli

Flask identification

Side arm

$0.5 \mathrm{ml}$. of disrupted bacterial preparation

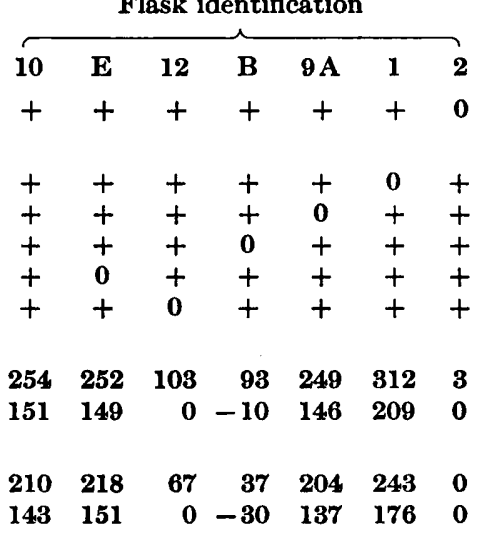

Main vessel

$0.5 \mathrm{ml} .0 .08 \mathrm{M}-$ methylene blue

$0.5 \mathrm{ml} .0 .01 \mathrm{M}-\mathrm{ATP}$

$0.5 \mathrm{ml}$. 0.004 M-DPN

$0.5 \mathrm{ml} .0 .001 \mathrm{M}-\mathrm{MgCl}_{2} \cdot 6 \mathrm{H}_{2} \mathrm{O}$

$0.5 \mathrm{ml}$. $0.04 \mathrm{M}$-glucose in $0.1 \mathrm{M}$-phosphate buffer $\mathbf{p H} 7 \cdot 0$

Expt. 1. $0_{2}$ uptake $\mu$ l. after $100 \mathrm{~min}$.

$\mathrm{O}_{2}$ uptake corrected for uptake without substrate $(103 \mu \mathrm{l}$.)

Expt. 2. $\mathrm{O}_{2}$ uptake $\mu$ l. after $120 \mathrm{~min}$.

$\mathrm{O}_{2}$ uptake corrected for uptake without substrate $(67 \mu \mathrm{l}$.) 
in flask 12 some component of the disrupted organism preparation was being oxidized, this reaction requiring DPN.

The $Q_{0}$, value for glucose calculated from the data in Table 3 flask 1 was 6.9, 1st experiment and $5 \cdot 8,2$ nd experiment. The average $Q_{\mathrm{o}_{2}}$ value for the intact organism was 100 , thus the activity of the disrupted organism was of the order of $1 / 17$ to $1 / 14$ of the intact.
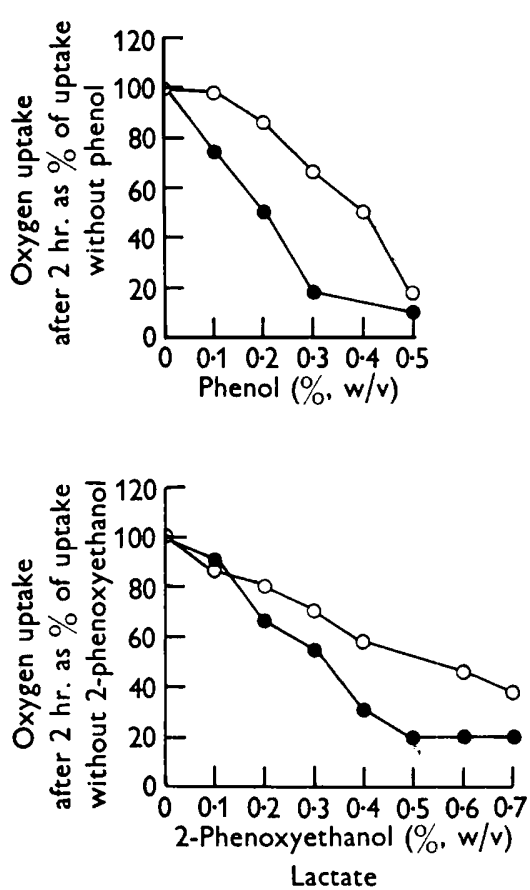

Fig. 2
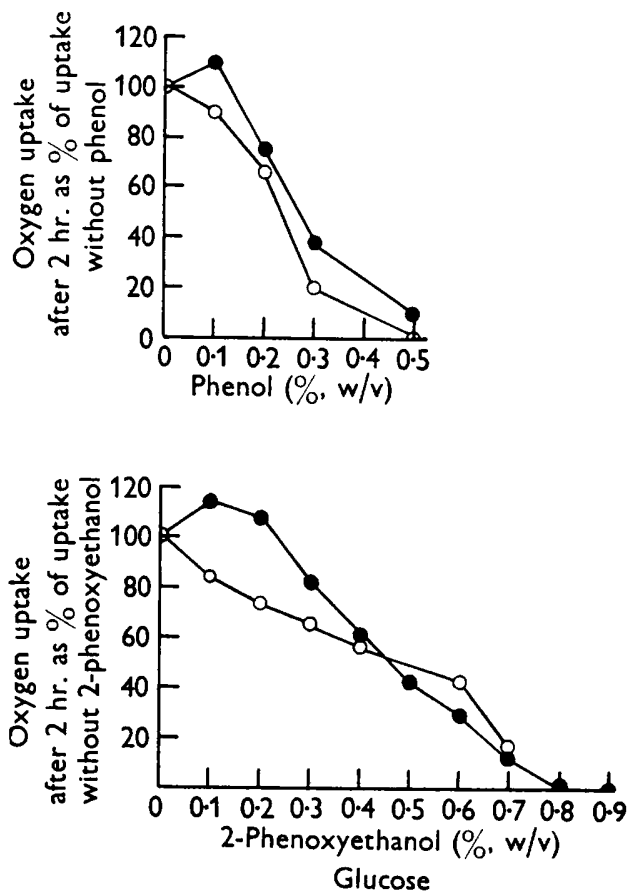

Fig. 3

Fig. 2. Comparison of the action of phenol and 2-phenoxyethanol on the oxidation of lactate by intact cells, - and a disrupted cell preparation, $\bigcirc-\bigcirc$, of Escherichia coli. Warburg flasks filled as follows: main compartment; $1.0 \mathrm{ml} .0 .02 \mathrm{M}$-lactate in $0.05 \mathrm{M}-$ phosphate buffer (pH 7.0), $0.5 \mathrm{ml}$. water or antiseptic solution. Side arm: $0.5 \mathrm{ml}$. intact cells or disrupted organism preparation. Centre well: $0.2 \mathrm{ml} .20 \% \mathbf{K O H}$ and filterpaper. 2-phenoxyethanol $(0.8-1.0 \%, \mathrm{w} / \mathrm{v} ; 0.06-0.07 \mathrm{M})$. Main compartment: $0.5 \mathrm{ml}$. of $0.4 \mathrm{M}$-lactate in $0.1 \mathrm{~m}$-buffer and $1.0 \mathrm{ml}$. of antiseptic solution. Duration of experiment $2 \mathrm{hr}$.

Fig. 3. Comparison of the action of phenol and 2-phenoxyethanol on the oxidation of glucose by intact cells, $\longrightarrow$, and a disrupted cell preparation, $\bigcirc-O$, of Escherichia coli. Warburg flask filled as follows: Main compartment: $0.5 \mathrm{ml}$. 0.04 M-glucose in $0.1 \mathrm{M}$ phosphate buffer (pH 7.0), 0.5 ml. 0.004 M-DPN, 0.5 ml. water or antiseptic solution. Side arm and centre well as in Fig. 2. 2-phenoxyethanol $(0.8$ and $1.0 \%$, w/v; 0.06$0.07 \mathrm{~m}$ ). Main compartment: $0.5 \mathrm{ml}$. 0.04 $\mathrm{M}$-glucose and $0.004 \mathrm{M}-\mathrm{DPN}$ in $0.1 \mathrm{M}$-buffer, $1 \mathrm{ml}$. antiseptic solution. Duration of experiment $2 \mathrm{hr}$.

Unlike the oxidation of lactate, the rate of oxidation of glucose often decreased during the course of the experiment. This decrease was traced to the presence of a DPN-destroying system in the disrupted organism preparation, as indicated by incubating the disrupted organism preparation with DPN for 
$6 \mathrm{hr}$. at $37^{\circ}$. On subsequent addition of glucose in phosphate buffer no oxygen uptake could be detected, nevertheless on the addition of fresh DPN, oxygen uptake occurred.

The action of phenol and 2-phenoxyethanol on the oxidation of lactate and of glucose by intact organisms and by the disrupted organism preparation was now compared.

Lactate oxidation. A typical experiment comparing results with a disrupted bacterial preparation and intact organisms is shown in Fig. 2. When lactate was supplied as substrate the disrupted preparation appeared less susceptible than the intact cell, but the difference in the $Q_{0_{2}}$ values of the intact and disrupted organism should be borne in mind.

Glucose oxidation. Results, with a disrupted bacterial preparation are compared in Fig. 3 with results observed with intact cells. Stimulation of oxygen uptake with glucose was not obtained with the disrupted preparation.

\section{DISCUSSION}

The results of the first two groups of experiments supported the view that the stimulation of oxygen uptake by phenol and 2-phenoxyethanol did not result from changes in the viable count or from an uncoupling effect such as is known to be the cause of the enhanced respiration occasioned by nitrophenols. Attention was therefore turned to the possibility that the antiseptics caused an increase in the permeability of the bacteria, thereby facilitating substrate oxidation. This led to the conclusion that the stimulation of oxygen uptake obtained with low concentrations of phenol and 2-phenoxyethanol in the presence of glucose, mannitol or lactose is explicable on the hypothesis that the enzyme or enzymes responsible for their oxidation are located within rather than at the surface of the organism, and that the first effect of the antiseptic is to effect a general increase in the permeability. Such an explanation would support the finding of Deere (1939) and of Gale \& Taylor (1947) that phenol was able to effect a general increase in the permeability of bacterial cells. The inhibition of oxygen uptake observed with other substrates at similar low concentrations of phenol or 2-phenoxyethanol would then presuppose that the enzymes concerned in these cases were at or near the surface of the organism and associated with centres at which the phenols were adsorbed. The glucose oxidizing system in the disrupted bacterial preparation studied in the present experiments showed no stimulation when treated with concentrations of the antiseptics which would have caused stimulation of the oxygen uptake of intact organisms. This supports the hypothesis that increased permeability resulting from the action of the anti-bacterial agent is the operative factor causing respiratory stimulation with those substrates; under the conditions of these experiments the rate of oxidation of certain substrates is probably limited by the rate of diffusion across a permeability barrier separating enzyme and substrate and this rate is increased by the antiseptic.

The action of CTAB (cetyltrimethylammonium bromide) calls for some comment. It has been shown by several workers (Gale \& Taylor, 1947; Salton, 
$1950,1951)$ that it causes an increase in permeability resulting in the leakage of cellular nitrogen and phosphorus into the external medium. In this respect its action is similar to that of phenol (Gale \& Taylor, 1947). It might therefore be expected that CTAB at low concentrations would cause the acceleration of oxygen uptake with the same group of substrates as phenol. Such respiratory stimulation was not detected in the experiments reported by Hugo \& Street (1952) nor in the work of Baker, Harrison \& Miller (1940) who examined a range of quarternary ammonium compounds. The large size of the CTAB cation and its net positive charge are both properties which distinguish it from phenol and 2-phenoxyethanol and the strong attraction of the cation for the negatively charged bacterial surface, although initiating outward diffusion of cellular components, may also retard the entry of substrates into the bacterial cell or their metabolism at the cell surface, thereby accounting for the inhibiting effect independent of substrate. Ample evidence for the strong adsorption of cationic antiseptics by Gram-negative bacteria has been obtained by electrophoretic studies (Dyar \& Ordal, 1946; McQuillen, 1950).

The production of pyruvic acid from glucose by the preparations of disrupted organisms is of interest. The present preparations resemble in some ways those prepared from Escherichia coli by Still (1940). Still's preparations converted hexosediphosphate to phosphoglyceric acid and required DPN for activity. It also seems that Still's preparation contained enolase, as sodium fluoride was included in the preparation 'to prevent formation of phosphopyruvic acid from phosphoglyceric acid'. In fermentation the DPN is reduced as a result of the oxidation of glyceraldehyde phosphate to diphosphoglyceric acid and is then re-oxidized by the simultaneous reduction of acetaldehyde, pyruvic acid or possibly other organic compounds with production of ethanol or lactic acid. Reduced DPN can however react with molecular oxygen provided a flavoprotein enzyme and one or more of the cytochrome pigments are present. There is thus presumptive evidence that the preparations used in the present investigation and those obtained by Still contained the components necessary for the reduction of molecular oxygen. Stimulation of oxygen uptake by low concentrations of phenol or 2-phenoxyethanol did not occur with intact organisms when oxidizing pyruvate. Thus the stimulated reaction must be one or more of those responsible for the conversion of glucose to pyruvate, and although this reaction is also carried out by the disrupted organism preparation stimulation did not occur. The pyruvate oxidizing system of the intact organisms is apparently not present in the disrupted cell preparation, or is inactivated or destroyed.

The oxidation of lactic acid proceeded without addition of cofactors and pyruvic acid was produced. Still (1941), with Escherichia coli, found that his cell-free preparations required methylene blue for activity with molecular oxygen. The activity of the preparations used in the present investigation was not increased in the presence of methylene blue. Knox, Auerbach, Zarvdnaya $\&$ Spirtes (1949) obtained an extract from a strain of $E$. coli, by grinding in the Booth-Green mill, which was able to react directly with molecular oxygen. 
The author acknowledges with thanks the help and advice of Professor H. E. Street, Department of Botany, University College, Swansea, during the course of this work and for helpful comments on the preparation of the paper, and thanks Dr G. E. Trease for facilities in the Department of Pharmacy.

\section{REFERENCES}

Baker, Z., Harrison, R. W. \& Miller, B. F. (1940). Action of synthetic detergents on the metabolism of bacteria. J. exp. Med, 73, 249.

Cavallini, D., Frontalli, N. \& Toschi, G. (1949). Determination of keto-acids by partition chromatography on filter paper. Nature, Lond. 163, 568.

Clifton, C. E. (1937). On the possibility of preventing assimilation in respiring cells. Enzymologia, 4, 246.

DEERE, C. J. (1939). On the activation of the lactase of Escherichia coli-mutabile. J. Bact. 37, 437.

Dyar, M. T. \& OrDal, E. J. (1946). Elektrokinetic studies on bacterial surfaces. I. The effects of surface-active agents on the electrophoretic mobilities of bacteria. J. Bact. 51, 149.

Gale, E. F. \& TAYlor, E. S. (1947). The action of tyrocidin and some detergent substances in releasing the amino-acids from the internal environment of Strep. faecalis. J. gen. Microbiol. 1, 77.

Hugo, W. B. \& STreet, H. E. (1952). The effect of phenol, 2-phenoxyethanol and cetyltrimethylammonium bromide on the oxidation of various substrates by Escherichia coli. J. gen. Microbiol. 6, 90.

Knox, W. E., Auerbach, V. H., Zarvdnaya, K. \& Spirtes, M. (1949). The action of cationic detergents on bacteria and bacterial enzymes. J. Bact. 58, 443.

McQuillen, K. (1950). The bacterial surface. I. The effect of cetyltrimethylammonium bromide on the electrophoretic mobility of certain Gram-positive bacteria. Biochim. biophys. Acta, 5, 463.

RACKer, E., (1950). Crystalline alcohol dehydrogenase from baker's yeast. J. biol. Chem. 184, 313.

Robertson, W. (1942). The preparation of sodium pyruvate. Science, $96,93$.

SAlton, M. R. J. (1950). The bactericidal properties of certain cationic detergents Aust. J. sci. Res. B, 3, 45.

SAlton, M. R. J. (1951). The adsorption of cetyltrimethylammonium bromide by bacteria, its action in releasing cellular constituents and its bactericidal effects. J. gen. Microbiol. 5, 391.

Shoupe, S. C. \& Krmler, A. (1934-5). The sensitivity of the respiration of luminous bacteria for 2:4-dinitrophenol. J. cell. comp. Physiol. 5, 269.

Still, J. L. (1940). Triosephosphate dehydrogenase of Bact. coli. Biochem. J. 34, 1374.

Still, J. L. (1941). Pyruvic dehydrogenase of Bact. coli. Biochem. J. 35, 380.

(Received 13 March 1956) 